\title{
Populational divergence in the impact of three nitrogenous compounds and their combination on larvae of the frog Pelophylax perezi (Seoane, 1885)
}

\author{
Andrés Egea-Serrano ${ }^{\mathrm{a}, *}$, Miguel Tejedo ${ }^{\mathrm{b}}$, Mar Torralva ${ }^{\mathrm{a}}$ \\ ${ }^{a}$ Departamento de Zoología y Antropología Física, Facultad de Biología, Universidad de Murcia, 30100 Murcia, Spain \\ ${ }^{\mathrm{b}}$ Departamento de Ecología Evolutiva, Estación Biológica de Doñana-CSIC, Avda. Americo Vespucio s/n, 41092 Sevilla, Spain
}

Keywords:

Populational divergence

Nitrogenous compounds

Nitrogenous mixtures

Amphibians

\begin{abstract}
a b s t r a c t
Pollution by nitrogenous compounds is a putative stressful factor that may be causally linked to the decline of amphibians. One way to understand the potentially detrimental consequences of eutrophication on amphibian populations is to investigate variation among populations differing in exposure to nitrogen, this variation potentially indicating evolutionary potential to cope with this stressor. We have examined the effect of nitrogenous compounds $\left(\mathrm{NH}_{4}^{\mathrm{p}}\right.$; $\mathrm{NO}_{2}^{-}$; $\mathrm{NO}_{3}^{-}$, both alone and in combination) on fitness-related larval traits in four populations of Pelophylax perezi naturally exposed to different degrees of eutrophication. The results indicate that both survival and larval final size decrease at higher concentrations of these compounds, either singly or in combination. Additionally, the nitrogenous compounds were more lethal and larval food consumption and final mass were significantly reduced when they were exposed to combinations of compounds. Populations inhabiting highly polluted aquatic environments tolerated higher levels of nitrogenous compounds and showed higher survival rates and larger final size than the populations of less polluted environments, suggesting the potential to adapt to increased nitrogenous contamination in this species.
\end{abstract}

\section{Introduction}

An important consequence of human activities is the profound alteration of the global nitrogen cycle, which in many areas increases both the availability and mobility of nitrogen. Fertilizers, animal wastes and atmospheric deposition are the main sources of nitrogenous compounds to the environment worldwide (Vitousek et al., 1997; Ritter and Bergstrom, 2001; Holland et al., 2005; Marco and Ortiz-Santaliestra, in press). As a consequence, pollution by nitrogenous compounds is widespread (Carpenter et al., 1998) and is expected to increase in the future (Tilman et al., 2001; Galloway et al., 2003). Thus, assessing the impact nitrogenous pollution on wildlife should be of major concern.

Although amphibian populations may show long-term natural, cyclic demographic fluctuations (Pechmann et al., 1991; Tejedo, 2003), their worldwide decline has been demonstrated (Houlahan et al., 2000; Stuart et al., 2004). Anthropogenic factors such as overexploitation, habitat loss, climatic change and disease have been argued as important causes of amphibian population decline (e.g. Stuart et al., 2004; Beebee and Griffiths, 2005). Among these factors, chemical pollution has been reported a major threat to amphibians (e.g. Beebee and Griffiths, 2005), and there is abundant evidence that these vertebrates are susceptible to the toxic effects

\footnotetext{
* Corresponding author. Tel.: +34 968364961; fax: +34 363963.

E-mail address: aegea@um.es (A. Egea-Serrano).
}

of nitrogenous compounds (e.g. Ortiz et al., 2004; Camargo et al., 2005; Marco and Ortiz-Santaliestra, in press).

Previous studies reported that nitrogenous compounds such as ammonium $\left(\mathrm{NH}_{4}^{\mathrm{p}}\right)$, nitrite $\left(\mathrm{NO}_{2}^{-}\right)$and nitrate $\left(\mathrm{NO}_{3}^{-}\right)$caused both lethal and sublethal effects on larval amphibians (e.g. $\mathrm{Xu}$ and Oldham, 1997; Marco et al., 1999; De Wijer et al., 2003; Burgett et al., 2007; Griffis-Kyle, 2007). Nitrate is the dominant form of nitrogen in water bodies with aerobic conditions (Camargo et al., 2005), where it is usually accompanied by other stress factors, including other nitrogen forms (e.g. Vidal-Abarca et al., 2000). Previous studies show that nitrogenous compounds in combination with other environmental factors such as UV-B radiation or pesticides (Hatch and Blaustein, 2000; Boone et al., 2005; Macías et al., 2007) affect amphibian embryos and larvae more severely than when they act alone. Despite the great relevance that such interactions may have on amphibian decline, to date no study on the mixture effects of multiple nitrogenous compounds has been carried out. In the present study, we hypothesized that increasing the number of nitrogenous compounds would negatively affect tadpole survival and performance.

Interspecific variation in nitrogen tolerance appears to be important in amphibian larvae (Marco et al.,1999; Marco and Ortiz-Santaliestra, in press). Nevertheless, information of intraspecific differences among populations in the sensitivity to nitrate compounds is almost totally lacking (but see Hecnar, 1995; Johansson et al., 2001; Hatch and Blaustein, 2003; Shinn et al., 
2008). Such information is likely to shed light on the evolutionary potential of nitrogen tolerance and would be therefore crucial for predicting the impact of these compounds on amphibian communities.

In this study we examine the effect of eutrophication on larvae of Pelophylax perezi. This species of waterfrog is widespread throughout the Iberian Peninsula and Southern France (Llorente and Arano, 1997) and mainly inhabits permanent water bodies (Díaz-Paniagua, 1990). As a consequence of farming practices (one of the most important nitrogen sources in nature (e.g. Ritter and Bergstrom, 2001), these habitats may hold high concentrations of different nitrogen forms. For instance, in southeastern Iberian Peninsula, concentrations as high as $154.6 \mathrm{mg} \mathrm{L}^{-1} \mathrm{NH}_{4}^{\mathrm{p}}$; $74.4 \mathrm{mg} \mathrm{L}^{-1} \mathrm{NO}_{2}^{-}$; $333 \mathrm{mg} \mathrm{L}{ }^{-1} \mathrm{NO}_{3}^{-}$have been recorded (Ballester, 2003; Suárez, personal communication). Because P. perezi uses water bodies as shelter from predators (Martín et al., 2006), for foraging (Docampo and Vega, 1990) and as breeding habitat (Egea-Serrano et al., 2005), nitrogen pollution may cause a threat to this species throughout its life cycle. The wide distribution and abundance of P. perezi even in highly eutrophic agricultural habitats (Llorente et al., 2002) means that there may be populations exposed to differing nitrogen concentration, which may cause interpopulational variation in tolerance to eutrophication, as has been shown in other species (e.g. Johansson et al., 2001).

The aims of the present study were (1) to determine the effects of exposure to different concentrations of $\mathrm{NH}_{4} \mathrm{Cl}, \mathrm{NaNO}_{2}$ and $\mathrm{NaNO}_{3}$, and some of their combinations, on mortality, food consumption and final mass of larvae of P. perezi; and, (2) to investigate the divergence in populations exposed to different levels of nitrate pollution that may arise from genetic adaptation in the tolerance to differing levels in nitrogen toxicity.

\section{Materials and methods}

\subsection{Studied populations}

Four populations of P. perezi located in the Segura River basin (SE Iberian Peninsula) (Fig. 1) were selected for the study. This basin is considered as one of the most arid of the Iberian Peninsula (Vidal-Abarca et al., 1987), and is undergoing an accelerated eutrophication (Ballester, 2003) due to intensive agricultural development in the area during the last decades (Pérez and Lemeunier, 2003). The selected populations were naturally exposed to different levels of nitrogen pollution. Two of these populations, considered control populations (C), were exposed to low nutrient concentrations: Río Chícamo (C1, hereafter) $\left(38^{\circ} 12^{\circ} \mathrm{N}, 001^{\circ} 03^{\circ} \mathrm{W}\right.$; 170.3 m.a.s.l.), a permanent headwater stream with less than $5.1 \mathrm{mg} \mathrm{L}^{-1} \mathrm{~N}^{-\mathrm{NO}_{3}^{-}}$(Vidal-Abarca et al., 2000); Rambla Tejera (C2, hereafter) $\left(38^{\circ} 11^{0} \mathrm{~N}, 002^{\circ} 07^{\circ} \mathrm{W} ; 1197.9\right.$ m.a.s.l.), a semipermanent headwater stream with less than $2.1 \mathrm{mg} \mathrm{L}^{-1} \mathrm{NO}_{3}^{-}$(A. Egea-Serrano, unpublished data). The environment of these populations corresponds to bush on marls (C1) or to a mixture of bush and pine trees on limestone lithology (C2). As a contrast to the above populations, two polluted populations (P) were selected: Rambla del Garruchal $\left(37^{\circ} 57^{\circ} \mathrm{N}, 001^{\circ} 04^{0} \mathrm{~W}\right.$; 346.0 m.a.s.l.) (herafter P1), a semipermanent headwater stream which has been exposed to nitrate concentrations as high as $162.1 \mathrm{mg} \mathrm{L}^{-1} \mathrm{NO}_{3}^{-}$for 22 years (Ballester, 2003) due to intensive farming activities and subsequent run-off in its basin, and Campus of Espinardo $\left(38^{\circ} 01^{\circ} \mathrm{N}, 001^{\circ} 10^{\circ} \mathrm{W}\right.$; 96.3 m.a.s.l.) (P2, hereafter), a small artificial pool located at the Espinardo Campus of the University of Murcia. Although no data concerning nutrient concentration levels are available for this population, episodic blooms of filamentous algae occurring at least for
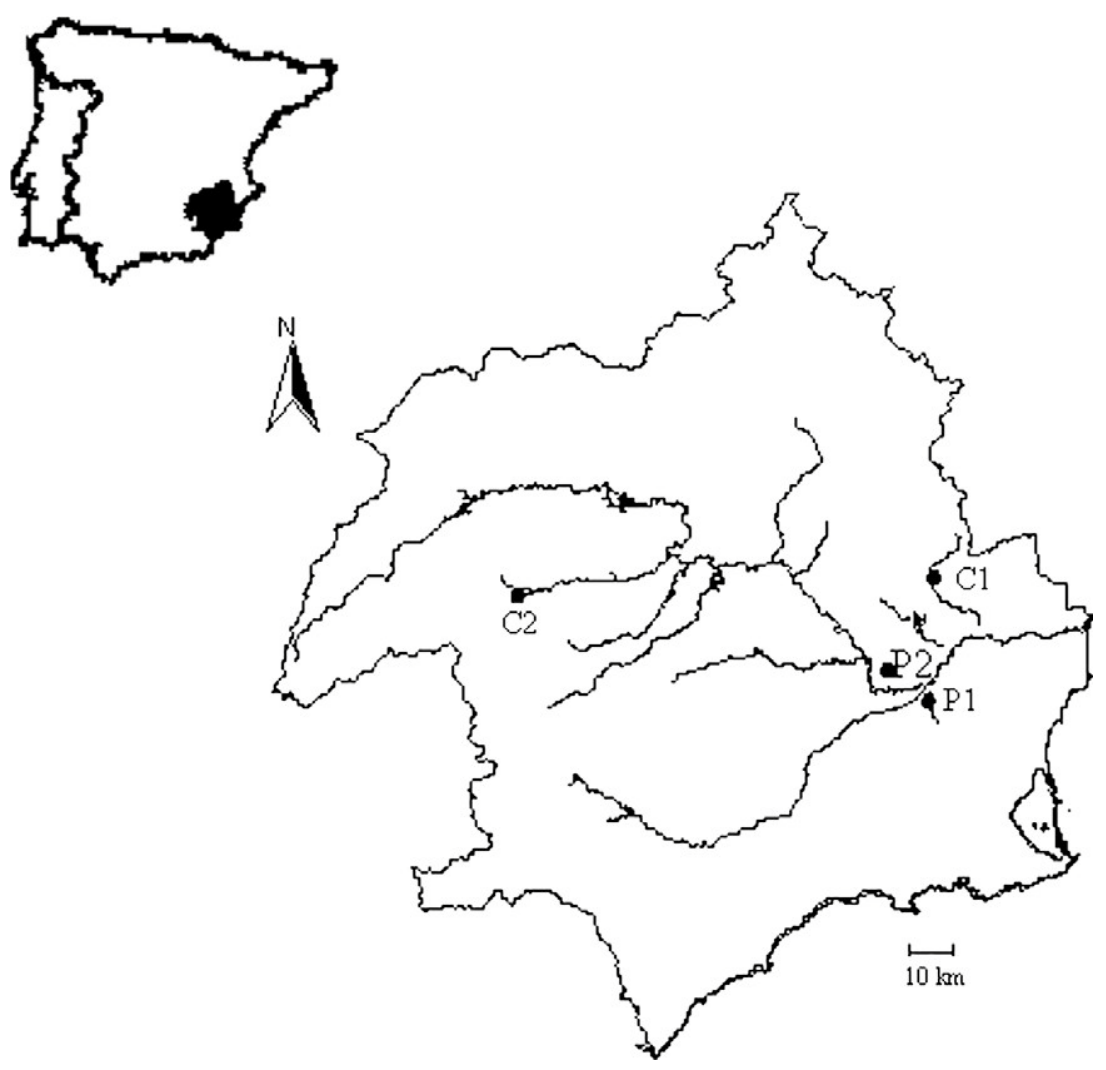

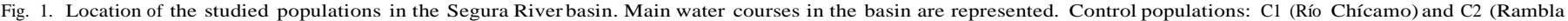
Tejera); polluted populations: P1 (Rambla del Garruchal) and P2 (Campus of Espinardo, University of Murcia). 
10 years (unpublished data) suggest substantial levels of eutrophication. The natural environment of P1 corresponds to pine trees on heterogeneous carbonated materials although most of the stream course has been largely modified and is dominated by intensive livestock farming. The P2 population environment corresponds to a suburban landscape. The geographical separation between populations ranged from 12.0 to $95.2 \mathrm{~km}$.

\subsection{Experimental design and response variables}

Five different egg masses of P. perezi were collected from each of the studied populations during 4-7 April 2006. The developmental stage of embryos collected ranged from stage 15 to 20 (Gosner, 1960), with no differences among populations (Chi-square, $P>0.05$ ). In all cases, embryos were transported before hatching to the laboratory, where they were reared in $12 \mathrm{~L}$ glass aquaria containing dechlorinated tap water $(\mathrm{pH}=8.39$; conductivity $=9851 \mathrm{~S} \mathrm{~cm}{ }^{-1} ; 0.002 \mathrm{mg} \mathrm{L}^{-1} \mathrm{NO}_{2}^{-} ; 4.69 \mathrm{mg} \mathrm{L}{ }^{-1} \mathrm{NO}_{3}^{-}$). Embryos from the same population of origin were pooled and reared in the same aquarium. Fully randomly selected larvae at Gosner stage 25 were individually transferred to $1 \mathrm{~L}$ plastic beakers containing $500 \mathrm{~mL}$ of the treatment solutions shown in Table 1. Each beaker was fully randomly assigned to one out of eight shelves in the laboratory. For the four studied populations the exposure started at the same time. Larvae were reared individually during the experiment. A sample of 13-15 experimental beakers were randomly chosen for each treatment to measure water $\mathrm{pH}$, temperature $\left({ }^{\circ} \mathrm{C}\right)$, conductivity $\left(\mathbf{I S ~ c m}{ }^{-1}\right)$ and salinity $\left(\mathrm{g} \mathrm{L}^{-1}\right)$. Measurements were taken just after applying treatments for first time. Ammonium, nitritre and nitrate concentrations were prepared using $\mathrm{NH}_{4} \mathrm{Cl}, \mathrm{NaNO}_{2}$ and $\mathrm{NaNO}_{3}$, respectively, and dechlorinated tap water. For each ion, two concentrations (low or high, Table 1) were selected to assess and magnify any subtle effect that may not have been detected at lower concentration. These concentrations are ecologically relevant, since they were representative of peak concentrations naturally occurring in the field in the Segura River basin (e.g. point sample: $154.6 \mathrm{mg} \mathrm{L}^{-1} \mathrm{NH}_{4}^{\text {p }} ; 74.4 \mathrm{mg} \mathrm{L}^{-1} \mathrm{NO}_{2}^{-}$; $333 \mathrm{mg} \mathrm{L}^{-1} \mathrm{NO}_{3}^{-}$, Suárez, personal communication). Since a major objective of the present study was to assess the impact of the treatments on sublethal parameters (food consumption and final mass), the concentrations selected for ammonium and nitrite were lower than those cited for the field because preliminary tests showed that higher concentrations produced high larval mortality after

Table 1

Nitrogen treatments used in this study.

\begin{tabular}{ll}
\hline Treatment & Concentration \\
\hline 1 & 0 \\
$2^{\text {A1a }}$ & $1.35 \mathrm{mg} \mathrm{L}^{-1} \mathrm{NH}_{4}^{\mathrm{p}}$ \\
$3^{\mathrm{A} 2 \mathrm{a}}$ & $13.5 \mathrm{mg} \mathrm{L}^{-1} \mathrm{NH}_{4}^{\mathrm{p}}$ \\
$4^{\mathrm{B} 1 \mathrm{a}}$ & $6.67 \mathrm{mg} \mathrm{L}^{-1} \mathrm{NO}_{2}^{-}$ \\
$5^{\text {B2a }}$ & $66.7 \mathrm{mg} \mathrm{L}^{-1} \mathrm{NO}_{2}^{-}$ \\
$6^{\mathrm{C} 1 \mathrm{a}}$ & $36.47 \mathrm{mg} \mathrm{L}^{-1} \mathrm{NO}_{3}^{-}$ \\
$7^{\mathrm{C} 2 \mathrm{a}}$ & $364.7 \mathrm{mg} \mathrm{L}^{-1} \mathrm{NO}_{3}^{-}$ \\
$8^{\mathrm{A} 1 \mathrm{~b} ; \text { B1b; C2b }}$ & $1.35 \mathrm{mg} \mathrm{L}^{-1} \mathrm{NH}_{4}^{\mathrm{p}}+364.7 \mathrm{mg} \mathrm{L}^{-1} \mathrm{NO}_{3}^{-}+6.67 \mathrm{mg} \mathrm{L}^{-1} \mathrm{NO}_{2}^{-}$ \\
$9^{\mathrm{A} 1 \mathrm{~b} ; \text { B2b; C2b }}$ & $1.35 \mathrm{mg} \mathrm{L}^{-1} \mathrm{NH}_{4}^{\mathrm{p}}+364.7 \mathrm{mg} \mathrm{L}^{-1} \mathrm{NO}_{3}^{-}+66.7 \mathrm{mg} \mathrm{L}^{-1} \mathrm{NO}_{2}^{-}$ \\
$10^{\mathrm{A} 2 \mathrm{~b} ; \text { B1b; C2b }}$ & $13.5 \mathrm{mg} \mathrm{L}^{-1} \mathrm{NH}_{4}^{\mathrm{p}}+364.7 \mathrm{mg} \mathrm{L}^{-1} \mathrm{NO}_{3}^{-}+6.67 \mathrm{mg} \mathrm{L}^{-1} \mathrm{NO}_{2}^{-}$ \\
$11^{\mathrm{A} 2 \mathrm{~b} ; \text { B2b; C2b }}$ & $13.5 \mathrm{mg} \mathrm{L}^{-1} \mathrm{NH}_{4}^{\mathrm{p}}+364.7 \mathrm{mg} \mathrm{L}^{-1} \mathrm{NO}_{3}^{-}+66.7 \mathrm{mg} \mathrm{L}^{-1} \mathrm{NO}_{2}^{-}$ \\
\hline
\end{tabular}

${ }^{\mathrm{A}}$ Treatments selected for the analysis of the separate effect of ammonium: 1: low concentration; 2: high concentration; a: ammonium isolated; b: ammonium combined with other nitrogenous compounds.

в Treatments selected for the analysis of the separate effect of nitrite: 1: low concentration; 2: high concentration; a: nitrite isolated; b: nitrite combined with other nitrogenous compounds.

C Treatments selected for the analysis of the separate effect of nitrate: 1: low concentration; 2: high concentration; a: nitrate isolated; b: nitrate combined with other nitrogenous compounds. short-term exposure (A. Egea-Serrano, unpublished data). Larvae were fed every three days with dry dog chow pellets (250$350 \mathrm{mg})$.

Larvae were exposed to the chemicals for 21 consecutive days in a laboratory at a roughly constant temperature $\left(25^{\circ} \mathrm{C}\right)$ and with indoor lighting of 12:12 h dark:light cycle. Water was renewed and the treatments restored every two days. The position of the beakers on the shelves was fully randomly re-assigned after each renewal. For C1 and C2 populations, each treatment was replicated seven times (i.e. seven larvae per treatment), whereas for P1 and P2 populations we had five replicates (i.e. five larvae per treatment) due to the limited number of larvae. Larval mortality at the end of the experiment was recorded and surviving larvae were weighed with an electronic balance $( \pm 0.0001 \mathrm{~g})$ after being blotted dry. Additionally, at days 7, 14 and 21, an estimate of larval food consumption was taken using the methodology proposed by Rist et al. (1997). Thus, a preweighed dried dog chow pellet (250$350 \mathrm{mg}$ ) was placed in each beaker with no other food source available. After $24 \mathrm{~h}$, the uneaten food was removed, dried again for $24 \mathrm{~h}$ at $50{ }^{\circ} \mathrm{C}$ and weighed. To correct for any bias in the estimates due to the loss of food by its handling or physical dilution in water a correction factor was calculated. To do so, a pilot study was performed with 50 dried dog chow pellets (250-350 mg). Each one was weighed, left in water without larvae for $24 \mathrm{~h}$ and weighed again after being dried for $24 \mathrm{~h}$ at $50{ }^{\circ} \mathrm{C}$. Final dried mass of the chow pellets (y) was regressed against their initial dried mass before being submerged $(\mathrm{x})$, obtaining the following regression equation: $y=-0.0082+0.8725 x \quad\left(R^{2}=0.988, P=0.0001, N=50\right)$. The initial dried mass of each chow pellet $(\mathrm{x})$ was introduced in this regression model to determine its final dried mass after removing the loss due to handling or dilution (y). The difference between this mass and the final dried mass weighed after chow pellets were in the experimental beakers with the larvae provided the amount of food eaten by each larva.

\subsection{Analysis of data}

The physicochemical characteristics of the water (dependent variables) were analysed separately using one-way ANOVAs with treatment as factor. Larval mortality was analysed by Generalized Linear Models (GLZ) for binary data fitting a binomial distribution of the data with a Logit Link function to yield maximum-likelihood ratio estimates, using environment of origin (non-polluted, involving $\mathrm{C} 1$ and C2 populations, vs polluted, involving P1 and P2 populations), population (nested within environment), treatment and their interaction as factors. Because GLZ analyses do not allow random factors, the mentioned factors were all considered as fixed factors. Since individuals were pooled and then fully randomly assigned to treatments, the random factor family could not be included in the analysis. Food consumption, measured as the mean value of the absolute amount of food eaten by each surviving larva for the three estimates taken, and final larval mass were analysed separately by General Linear Models (GLM), using the fixed factors treatment and environment of origin, and the random factor population (nested within environment), as well as their interactions, as independent factors. We used post hoc HDS Tukey tests for pairwise comparisons for the treatment factor in the case of the response variables food consumption and larval final mass. Additionally, the effect of compound concentration and mixture on the response variables was analysed in more detail for each nitrogenous compound separately using GLZ (in the case of larval mortality) and GLM (for food consumption and final mass). To do so, treatments containing the compound of interest were selected and assigned to the proper category of the factors concentration (low or high) and mixture (single or combined with the rest of compounds, regardless their concentration) (Table 1). Environment 
Table 2

Physicochemical characteristics (mean \pm 1SE) of the water used in the nitrogen treatments. Lower case letters indicate homogenous groups in pairwise-comparisons (HDS Tukey's test, $a=5 \%$ ). Only variables significantly affected by treatments are shown.

\begin{tabular}{lll}
\hline Treatment & Conductivity $\left(1 \mathrm{~s} \mathrm{~cm}^{-1}\right)$ & Salinity $\left(\mathrm{g} \mathrm{L}^{-1}\right)$ \\
\hline $1(\mathrm{n}=15)$ & $1265.73 \pm 4.85 \mathrm{a}$ & $0.41 \pm 0.007 \mathrm{a}$ \\
$2(\mathrm{n}=15)$ & $1274.80 \pm 4.79 \mathrm{a}$ & $0.41 \pm 0.007 \mathrm{a}$ \\
$3(\mathrm{n}=15)$ & $1345.80 \pm 4.93 \mathrm{~b}$ & $0.50 \pm 0 \mathrm{~b}$ \\
$4(\mathrm{n}=15)$ & $1288.33 \pm 7.54 \mathrm{a}, \mathrm{b}$ & $0.42 \pm 0.011 \mathrm{a}$ \\
$5(\mathrm{n}=15)$ & $1394.13 \pm 9.82 \mathrm{~b}$ & $0.50 \pm 0 \mathrm{~b}$ \\
$6(\mathrm{n}=14)$ & $1321.21 \pm 5.85 \mathrm{a}, \mathrm{b}$ & $0.48 \pm 0.011 \mathrm{~b}$ \\
$7(\mathrm{n}=15)$ & $1799.93 \pm 43.58 \mathrm{c}$ & $0.78 \pm 0.011 \mathrm{c}$ \\
$8(\mathrm{n}=15)$ & $1883.07 \pm 10.95 \mathrm{e}$ & $0.80 \pm 0 \mathrm{c}$ \\
$9(\mathrm{n}=13)$ & $1994.15 \pm 10.16 \mathrm{~d}, \mathrm{f}$ & $0.88 \pm 0.012 \mathrm{~d}, \mathrm{e}$ \\
$10(\mathrm{n}=13)$ & $1966.08 \pm 8.93 \mathrm{e}, \mathrm{f}$ & $0.84 \pm 0.014 \mathrm{c}, \mathrm{e}$ \\
$11(\mathrm{n}=15)$ & $2076.00 \pm 11.08 \mathrm{~d}$ & $0.90 \pm 0 d$ \\
\hline
\end{tabular}

of origin, concentration, mixture and their different interactions were included as fixed factors. To analyze for the effect of population of origin, this random factor was also included in the analyses, nested within environment (in the case of larval mortality it was considered as a fixed factor, as mentioned above). Significance levels were not corrected for multiple comparisons because comparisons among different pollutants were based on a priori hypotheses.

All variables were $\log$-transformed $(\log (x+1))$ except mortality. GLZ for binary data were performed using STATISTICA 6.0 statistical package (Statsoft, Inc. 2001). The rest of the analyses were performed with SPSS $^{\circledR}$ v. 15.0 statistical package. In all cases a significant level of $5 \%$ was selected and descriptive statisticals were expressed as mean $\pm 1 \mathrm{SE}$.

\section{Results}

\subsection{Water physicochemical characteristics}

Water $\mathrm{pH}$ and temperature ranged from 6.85 to 8.04 and from 20.0 to $24.8{ }^{\circ} \mathrm{C}$, respectively. Nitrogen treatments did not affect these parameters $(\mathrm{P}>0.10$ in both cases). Water conductivity $\left(\mathrm{F}_{10,149}=390 ; \quad \mathrm{P}=0.0001\right)$ and salinity $\left(\mathrm{F}_{10,149}=524.33 ; \quad \mathrm{P}=\right.$ 0.0001 ) differed across treatments, being significantly greater at high concentrations of ammonium, nitrite and nitrate, whether isolated or combined (Table 2).

\subsection{Effects on mortality}

Larval mortality was significantly affected by nitrogen treatment and environment of origin (Table 3). Treatments involving high concentrations of ammonium, both isolated and combined with other nitrogenous compounds (treatments 3, 10 and 11, Table 4 , significant environment $\times$ concentration interaction), increased larval mortality in relation to the rest of treatments (Fig. 2). This severe effect of high concentration of ammonium compared with lower concentration was also observed when the effects of this compound were analysed separately (Table 4). In addition, the separate analysis on the treatments with nitrite showed that exposure to nitrite in combination with ammonium and nitrate significantly increased larval mortality as compared to exposure to nitrite only (Table 4, Fig. 2). Larvae from non-polluted populations showed higher mortality than polluted ones (Fig. 2), as revealed both by the analysis of all treatments (Table 3 ) and by the analyses performed for each nitrogenous compound separately (Table 4). The significant environment $\times$ treatment interaction (Table 3) revealed that the pattern of divergence in larval mortality between different environments of origin differed across treatments. Polluted populations had lower larval mortalities than reference populations only for high levels of ammonium, whether isolated or in combination (Fig. 2, treatments 3, 10 and 11, Table 4, significant environment $\times$ concentration interaction) suggesting differential sensitivity to ammonium between source environments, possibly indicating local adaptation to this toxicant. This environment-specific response also arose when the effect of ammonium was analysed separately, which also revealed that the exposure to the combination of nitrogenous compounds aggravated the effects of isolated ammonium to some degree, as suggested by the significant concentration $\times$ mixture interaction (Table 4 ).

\subsection{Effects on averaged food consumption}

The amount of food consumed by larvae was significantly affected by nitrogen treatment (Table 3). Exposure to nitrogenous compounds produced lower feeding rates than in control larvae (planned comparison, $\mathrm{F}_{1,166}=292.024, \mathrm{P}=0.0001$ ). Additionally, larvae exposed to nitrogenous mixtures consumed significantly less food than those exposed to individual pollutants (Fig. 3), as revealed by the analysis of the effect of all treatments (Table 3) and by the separate analysis of the effect of each nitrogenous compound (Table 4). Food consumption responses differed among the studied populations (significant environment $\times$ treatment

Table 3

Summary statistics for the GLZ and GLM analyses on mortality, food consumption and final mass of larvae of P. perezi in the laboratory. Significant values are shown in bold.

\begin{tabular}{|c|c|c|c|c|c|c|}
\hline Variable & Source of variation & & df & & $\mathbf{q}^{2}$ & $\mathrm{P}$ \\
\hline \multirow[t]{6}{*}{ Mortality } & Environment & & 1 & & 15,481 & 0.0001 \\
\hline & Population (Environment) & & 2 & & 3223 & 0.200 \\
\hline & Treatment & & 10 & & 65,667 & 0.0001 \\
\hline & Environment $\times$ treatment & & 10 & & 23,068 & 0.011 \\
\hline & Population $($ Environment) $\times$ treatment & & 20 & & 21,887 & 0.347 \\
\hline & Source of variation & df numerator & & df denominator & $\mathrm{F}$ & $\mathrm{P}$ \\
\hline \multirow{5}{*}{$\begin{array}{l}\text { Food } \\
\text { consumption }\end{array}$} & Environment & 1 & & 1.991 & 12.319 & 0.073 \\
\hline & Population (Environment) & 2 & & 16.866 & 0.573 & 0.575 \\
\hline & Treatment & 10 & & 17.987 & 121.553 & 0.0001 \\
\hline & Environment $\times$ treatment & 10 & & 18.058 & 5.949 & 0.001 \\
\hline & Population (Environment) $\times$ treatment & 17 & & 166 & 3.048 & 0.0001 \\
\hline \multirow[t]{5}{*}{ Final weight } & Environment & 1 & & 2.000 & 1.829 & 0.309 \\
\hline & Population (Environment) & 2 & & 24.454 & 13.020 & 0.0001 \\
\hline & Treatment & 10 & & 20.382 & 1.721 & 0.144 \\
\hline & Environment $\times$ treatment & 10 & & 20.453 & 0.881 & 0.565 \\
\hline & Population (Environment) $\times$ treatment & 19 & & 169 & 1.445 & 0.112 \\
\hline
\end{tabular}




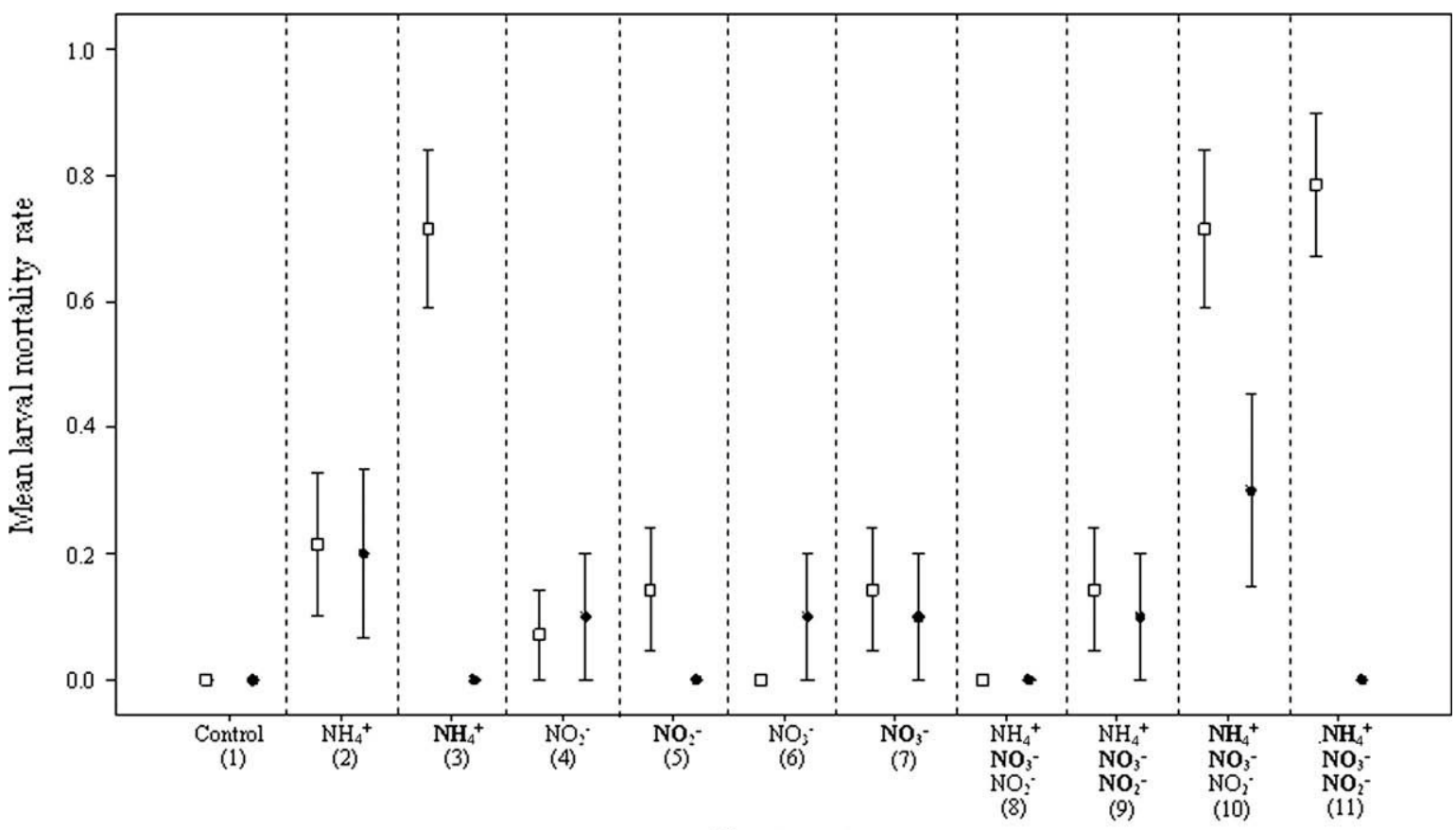

Treatment

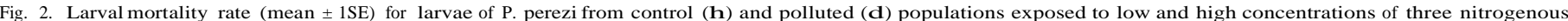

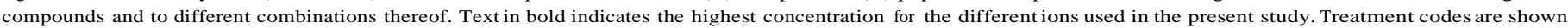
in brackets (see Table 1 for details).

Table 4

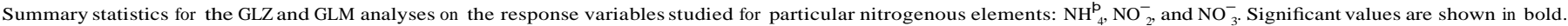
ndf: numerator degrees of freedom; ddf: denominator degrees of freedom.

\begin{tabular}{|c|c|c|c|c|c|c|c|c|c|c|c|c|c|}
\hline \multirow[t]{2}{*}{ Variable } & \multirow[t]{2}{*}{ Source of variation } & \multicolumn{2}{|c|}{$\mathrm{NH}_{4}^{\mathrm{p}}$} & \multirow[b]{2}{*}{$\mathbf{q}^{2}$} & \multicolumn{4}{|c|}{$\mathrm{NO}_{2}^{-}$} & \multicolumn{5}{|c|}{$\mathrm{NO}_{3}^{-}$} \\
\hline & & \multicolumn{2}{|c|}{ ndf } & & \multicolumn{2}{|l|}{$\mathrm{P}$} & ndf & $\mathbf{q}^{2}$ & \multicolumn{2}{|l|}{$\mathrm{P}$} & $\overline{\text { ndf }}$ & $\mathbf{q}^{2}$ & \multirow{2}{*}{$\mathrm{P}$} \\
\hline \multirow[t]{9}{*}{ Mortality } & Environment: ENV & \multicolumn{2}{|c|}{1} & 20.109 & 0.0001 & \multicolumn{2}{|c|}{1} & 11.644 & 0.0006 & \multicolumn{2}{|r|}{1} & 11.206 & \\
\hline & Population (ENV) & \multicolumn{2}{|c|}{2} & 4.697 & 0.0955 & \multicolumn{2}{|c|}{2} & 7.877 & 0.0195 & \multicolumn{2}{|r|}{2} & 2.193 & 0.3340 \\
\hline & Concentration: CON & \multicolumn{2}{|c|}{1} & 27.866 & 0.0001 & \multicolumn{2}{|c|}{1} & 0.044 & 0.8331 & \multicolumn{2}{|r|}{1} & 1.140 & 0.2856 \\
\hline & Mixture: MIX & \multicolumn{2}{|c|}{1} & 0.222 & 0.6377 & \multicolumn{2}{|c|}{1} & 8.997 & 0.0027 & \multicolumn{2}{|r|}{1} & 3.031 & $0.0817^{1}$ \\
\hline & $\mathrm{CON} \times \mathrm{MIX}$ & \multicolumn{2}{|c|}{1} & 4.059 & 0.0439 & \multicolumn{2}{|c|}{1} & 0.001 & 0.9813 & & NM & NM & NM \\
\hline & $\mathrm{ENV} \times \mathrm{CON}$ & & & 7.926 & 0.0049 & & & 3.059 & 0.0802 & & 1 & 1.786 & $0.1814^{\mathrm{a}}$ \\
\hline & $\mathrm{ENV} \times$ MIX & & & 0.111 & 0.7391 & & & 0.506 & 0.4767 & & 1 & 0.895 & $0.3340^{\mathrm{b}}$ \\
\hline & $\mathrm{ENV} \times \mathrm{CON} \times \mathrm{MIX}$ & & & 1.497 & 0.2210 & & & 0.546 & 0.4598 & & NM & NM & NM \\
\hline & Source of variation & ndf & ddf & $\mathrm{F}$ & $P$ & ndf & ddf & F & $\mathrm{P}$ & ndf & ddf & F & $P$ \\
\hline Food & Environment: ENV & 1 & 2.933 & 0.412 & 0.5676 & 1 & 2.155 & 19.032 & 0.0425 & 1 & 32.597 & 11.948 & 0.0015 \\
\hline Consumption & Population (ENV) & 2 & 85 & 1.618 & 0.2043 & 2 & 96 & 1.066 & 0.3485 & 2 & 77 & 0.088 & 0.9157 \\
\hline & Concentration (CON) & 1 & 85 & 33.135 & 0.0001 & 1 & 96 & 5.768 & 0.0182 & 1 & 36 & 105.685 & 0.0001 \\
\hline & Mixture (MIX) & 1 & 85 & 1289.463 & 0.0001 & 1 & 96 & 1176.560 & 0.0001 & 1 & 77 & 63.787 & $0.0001^{\prime}$ \\
\hline & $\mathrm{CON} \times \mathrm{MIX}$ & 1 & 85 & 63.139 & 0.0001 & 1 & 96 & 89.873 & 0.0001 & NM & & NM & NM \\
\hline & $\mathrm{ENV} \times \mathrm{CON}$ & 1 & 85 & 0.449 & 0.5048 & 1 & 96 & 49.508 & 0.0001 & 1 & 36 & 0.087 & $0.7696^{a}$ \\
\hline & $\mathrm{ENV} \times \mathrm{MIX}$ & 1 & 85 & 4.746 & 0.0321 & 1 & 96 & 0.537 & 0.4654 & 1 & 77 & 0.242 & $0.6239^{b}$ \\
\hline & $\mathrm{ENV} \times \mathrm{CON} \times \mathrm{MIX}$ & 1 & 85 & 1.746 & 0.1898 & 1 & 96 & 70.063 & 0.0001 & NM & & NM & NM \\
\hline Mass & Environment: ENV & 1 & 2117 & 2.785 & 0.2302 & 1 & 2031 & 4.034 & 0.1804 & 1 & 2167 & 1.141 & 0.3897 \\
\hline & Population (ENV) & 2 & 91 & 11.430 & 0.0001 & 2 & 101 & 7.430 & 0.0009 & 2 & 83 & 9.669 & 0.0002 \\
\hline & Concentration (CON) & 1 & 91 & 7.122 & 0.0090 & 1 & 101 & 5.082 & 0.0263 & 1 & 36 & 0.224 & 0.6386 \\
\hline & Mixture (MIX) & 1 & 91 & 0.027 & 0.8699 & 1 & 101 & 0.002 & 0.9634 & 1 & 83 & 1.724 & $0.1928^{1}$ \\
\hline & $\mathrm{CON} \times \mathrm{MIX}$ & 1 & 91 & 0.856 & 0.3573 & 1 & 101 & 6.512 & 0.0122 & NM & & NM & NM \\
\hline & $\mathrm{ENV} \times \mathrm{CON}$ & 1 & 91 & 0.006 & 0.9372 & 1 & 101 & 0.433 & 0.5118 & 1 & 36 & 1.337 & $0.2548^{\mathrm{a}}$ \\
\hline & $\mathrm{ENV} \times \mathrm{MIX}$ & 1 & 91 & 1.530 & 0.2192 & 1 & 101 & 0.501 & 0.4807 & 1 & 83 & 0.127 & $0.7225^{b}$ \\
\hline & $\mathrm{ENV} \times \mathrm{CON} \times \mathrm{MIX}$ & 1 & 91 & 0.151 & 0.6988 & 1 & 101 & 1.027 & 0.3132 & NM & & NM & NM \\
\hline
\end{tabular}

a These sources of variation were estimated only for isolated $\mathrm{NO}_{3}^{-}$.

b These sources of variation were estimated only for high concentration of $\mathrm{NO}_{3}^{-}$; $\mathrm{NM}$ : non measurable sources of variation.

interaction, $\mathrm{P}<0.001$, Table 3). Polluted populations ate more food than non-polluted populations in the treatments with higher levels of nitrite (Fig. 3, treatments 5 and 11), whereas the amount of food consumed was lower than in the case of non-polluted populations for the treatment involving low concentration of ammonium (Fig. 3, treatment 2). When separate analyses were performed for each nitrogenous compound, larvae from polluted populations ate more food than non-polluted populations when 


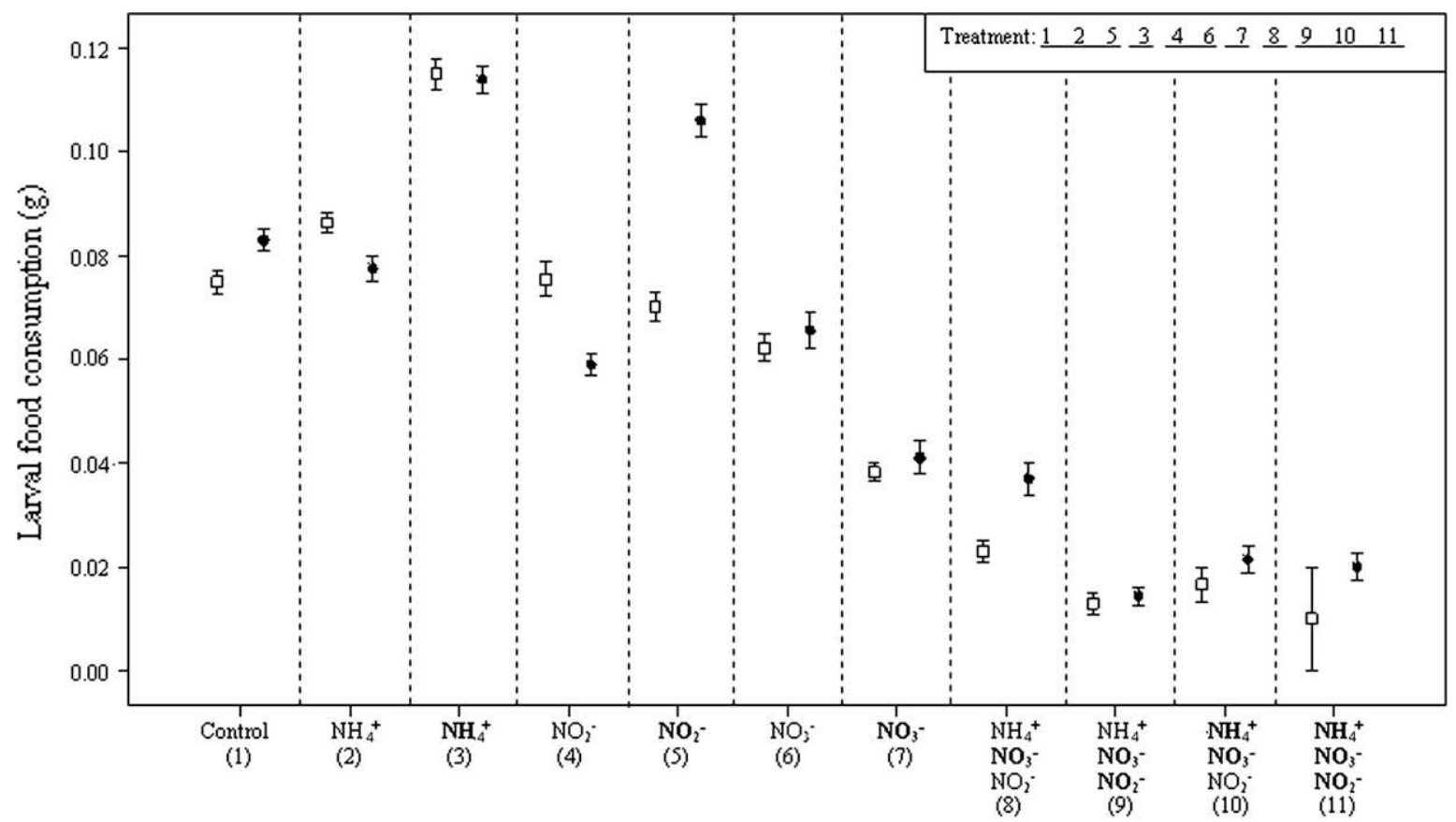

\section{Treatment}

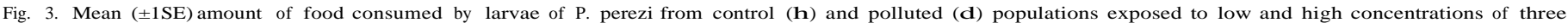

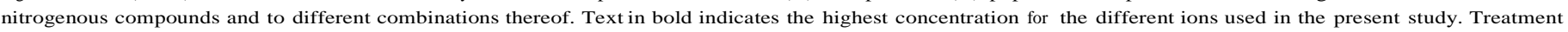

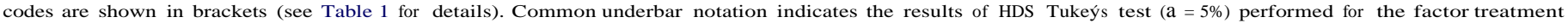
(treatment codes underlined by the same bar correspond to homogenous groups).

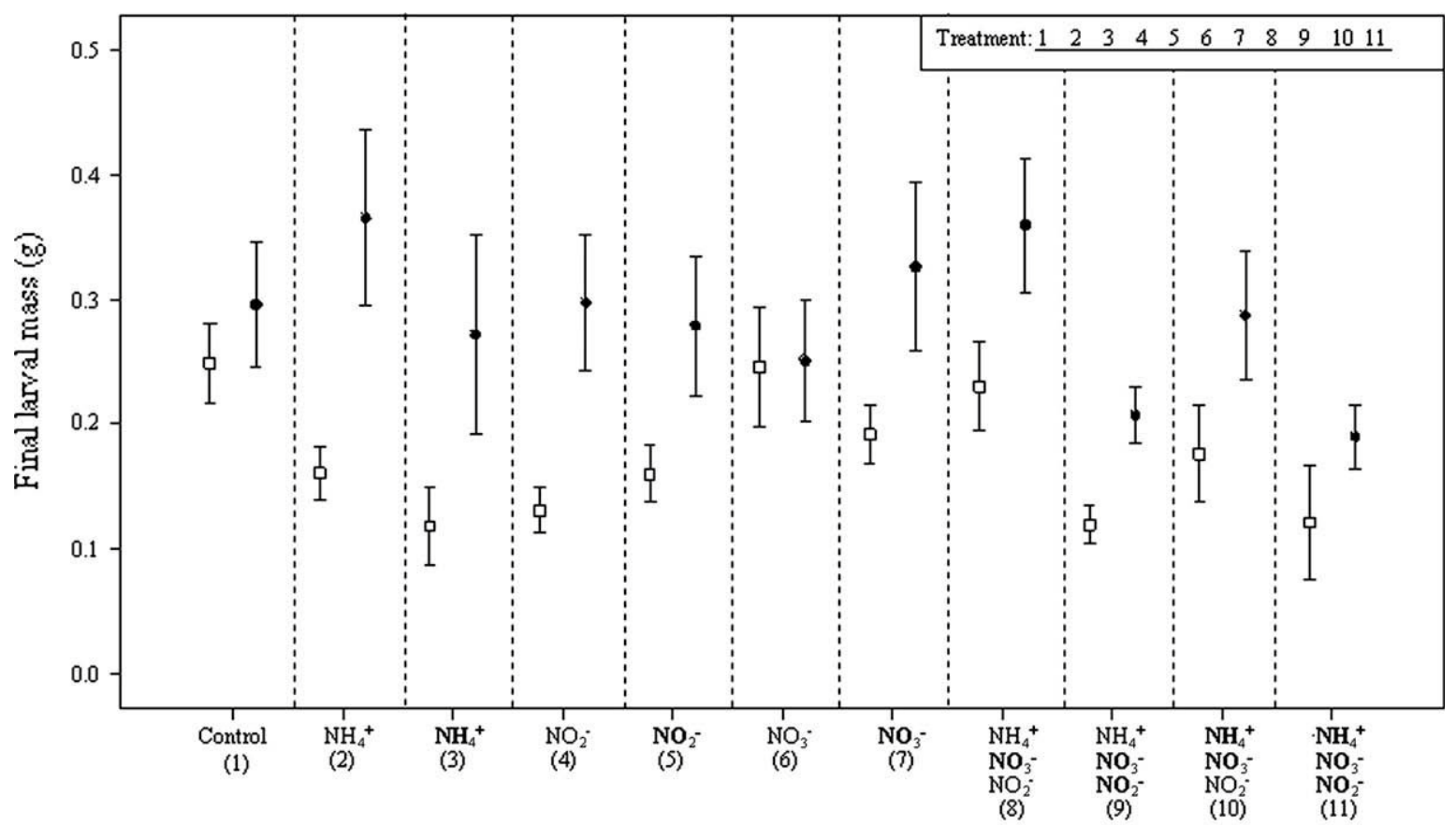

Treatment

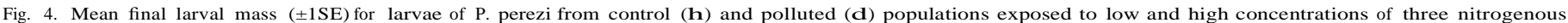

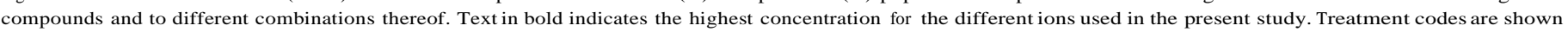

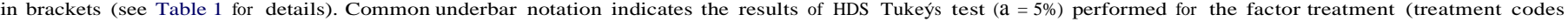
underlined by the same bar correspond to homogenous groups).

they were exposed to ammonium in combination with nitrite and nitrate (Table 4, Fig. 3, treatments 8-11) and when they were exposed to high levels of nitrite (Table 4, Fig. 3, treatments 5, 9 and
11). Moreover, significant concentration $\times$ mixture interactions were observed for the separate analysis for ammonium and nitrite (Table 4), suggesting that the combination of nitrogenous 
compounds severely reduced the amount of food consumed by larvae as compared to the exposure to ammonium and nitrite alone.

\subsection{Effects on final mass}

Final larval mass was unaffected by treatment, environment of origin, or their interaction. Only population (nested within environment) significantly affected final mass (Table 3). Larvae from P1 reached a greater size (final mass, mean $\pm 1 \mathrm{SE}$ : $0.350 \pm 0.023 \mathrm{~g}$, $\mathrm{N}=53$ ) than larvae from the other populations (final mass, mean \pm 1SE: C1: $0.178 \pm 0.017 \mathrm{~g}, \mathrm{~N}=55$; $\mathrm{C} 2: 0.191 \pm 0.013 \mathrm{~g}, \mathrm{~N}=57$; P2: $0.211 \pm 0.019 \mathrm{~g}, \mathrm{~N}=47$ ) (Table 3). This pattern was also observed when the effect of ammonium, nitrite and nitrate was analysed separately (Table 4). These separate analyses, however, revealed that the treatments with high concentrations of ammonium and nitrite led to lower final mass in the tadpoles than lower concentrations of these toxicants (Table 4, Fig. 4). Moreover, this decrease in mass at high concentration of nitrite was more pronounced when nitrite was combined with other nitrogen forms (significant concentration $\times$ mixture interaction, Table 4, Fig. 4, treatments 9 and 11).

\section{Discussion}

The results obtained indicated three basic conclusions: (1) Exposure of P. perezi tadpoles to nitrogenous treatments strongly reduced larval survival and food consumption and caused a slight decrease in final larval mass. (2) Exposure to pollutant combinations produced more severe effects in relation to nitrogenous compounds acting isolately for the response variables larval mortality and food uptake. (3) A noticeable degree of interpopulational variation was detected for larval mortality and food consumption; larvae from polluted sites being more tolerant than those from low nitrate stress environments.

Previous studies have reported that exposure to high levels of ammonium (Jofre and Karasov, 1999; Schuytema and Nebeker, 1999a), nitrite (Marco et al., 1999; Griffis-Kyle, 2005, 2007; Macías et al., 2007; Shinn et al., 2008) and nitrate (Baker and Waights, 1993, 1994; Schuytema and Nebeker, 1999a,b; Smith et al., 2005) increase larval amphibian mortality. The present study indicates that high concentrations of ammonium, whether isolated or combined with other nitrogen compounds, caused significant mortality. Moreover, when the effects of each compound were analysed separately, a significant increase of larval mortality was detected when nitrite acted in combination with ammonium and nitrate as compared to its effect as a single stressor. This apparent lack of effect of nitrate and nitrite when they act as single stressors supports previous studies on several frog species (Smith et al., 2004; Vaala et al., 2004; Smith, 2007). The existence of an effective detoxification pathway may explain the observed tolerance to nitrite and nitrate ions, as has been hypothesized for Lithobates catesbeianus tadpoles suffering short-term nitrite exposure (Huey and Beitinger, 1980a). Additionally, the chlorides present in the dechlorinated tap water used in the experiment $\left(110 \mathrm{mg} \mathrm{L}^{-1} \mathrm{Cl}^{-}\right)$ (or any other monovalent ion) may have competed with nitrite for ionic uptake sites on the respiratory surface (Huey and Beitinger, 1980a,b), reducing its overall uptake and, consequently, its effects. These considerations emphasize the importance of performing physiological studies to identify the mechanisms underlying the divergent tolerance levels of the studied species to different nitrogenous compounds.

The general reduction in food ingestion observed in the presence of high nitrogenous concentrations also supports previous studies (Baker and Waights, 1993, 1994; Hecnar, 1995; Xu and
Oldham, 1997; but see Watt and Oldham, 1995). Since treatments were renewed every two days, preventing algal growth, no alternative food source was available in the experimental beakers. Moreover, the effects observed cannot be attributed to the fact that larvae exposed to polluted treatments were more inactive, since larval activity level increased for those treatments significantly affecting this response variable (Egea-Serrano et al., unpublished data). Thus, the observed lower food consumption may either be regarded as a disturbance response of the symbiotic gut bacteria involved in digestion (Hecnar, 1995) or an alteration in the chemosensory system of the larvae, which is essential for food detection (Veeranagoudar et al., 2004). However, these arguments do not explain the contrary trend observed in larvae exposed to high concentrations of ammonium and nitrite (for polluted populations), which increased their food uptake. A possible explanation for this enhanced ingestion may be the need to satisfy the increased energetic costs that detoxification pathways would demand (Wright and Wright, 1996).

The exposure to nitrogenous compounds has been shown to produce a diversity of responses in amphibian larvae growth in laboratory conditions. Some studies observed no significant effect of fertilizers on final larval size (Hecnar, 1995; Vaala et al., 2004; Smith et al., 2005), whereas others mentioned that such exposure reduced the final size of the larvae (e.g. Griffis-Kyle, 2007; Shinn et al., 2008). Considering the separate analyses for each compound, our results would support this last scenario (at least in the case of ammonium and nitrite), although no significant effects were detected when the data for the eleven treatments included in the present study were considered jointly. As treatments significantly affected the amount of food consumed, we predicted that treatments where larvae consumed greater amounts of food would lead to a larger final mass. However, this prediction was not supported by any significant relationship between final mass and food consumed (Pearson correlation: $r=0.042, P=0.546, N=206$ ). Larval growth may be affected by the physicochemical characteristics of water such as $\mathrm{pH}$ or temperature (Álvarez and Nicieza, 2002; Glos et al., 2003). In our study, these parameters did not significantly differ and, as a consequence, their effect on the results recorded may be insignificant. Nevertheless, those treatments corresponding to high concentration of nitrate, as well as to the mixtures of nitrogenous compounds, showed significantly higher water conductivity and salinity than the rest. Exposure to these conditions may have induced osmotic stress that affected growth, such as described in previous studies (Gómez-Mestre et al., 2004; Ortiz-Santaliestra, 2008) and which may have biased the results obtained. In addition, the increased energetic costs that detoxification pathways may involve in the case of the exposure to high concentrations of ammonium and, for P1 and P2 populations, nitrite (Wright and Wright, 1996) would probably have led to a lack of effect on final mass, in spite of the increased amount of food consumed by larvae exposed to these treatments. Further physiological studies are needed to identify the mechanisms responsible for the apparent lack of effect of individual pollution treatments on final larval mass in P. perezi. Nevertheless, to fully assess the consequences of nitrogenous pollution on larval mass in the studied species, experiments in more natural environments are needed since nitrogenous compounds may have indirect effects through the alteration of primary producers and microbial communities (Carpenter et al., 1998; Fenn et al., 2003), which may produce positive effects on the mass of surviving tadpoles (e.g. De Wijer et al., 2003).

The exposure to cocktails of fertilizers and other stressing factors, such as pesticides (Boone et al., 2005), UV-B radiation (Hatch and Blaustein, 2000, 2003; Macías et al., 2007) or low $\mathrm{pH}$ (Hatch and Blaustein, 2000) may affect amphibian larvae more severely than when they are exposed to these factors acting in 
isolation (but see Boone and Bridges-Britton, 2006). The response to a cocktail of stressors may be either additive or synergistic (Berenbaum, 1989). In the present study, the exposure of larvae to the combination of different nitrogenous compounds at different concentrations affected larval mortality and food consumption more severely than the exposure to single compounds, in contrast to previous studies in which no different effects were recorded in relation to those produced by isolated factors (Orton et al., 2006) or control treatments (Boone and Bridges-Britton, 2006). Moreover, the separate analyses performed for each one of the nitrogenous compounds studied suggests that the exposure to the combination of such compounds would have a synergistic effect on mortality, food consumption and even final mass. Nevertheless this interpretation needs to be considered cautiously because the greater effect of the combination of nitrogenous compounds may be due to their higher total amount of nitrogen, rather than to a true interaction among compounds. More research involving pairwise combinations of pollutants is needed to evaluate the effects of nitrogenous mixtures independently of the cumulative nitrogen effects and to properly assess whether such mixtures interact synergisticaly or additively.

The response to nitrogenous pollution differed between populations that were naturally exposed to different levels of nitrogenous pollution in their aquatic habitats. As regards larval mortality, two populations breeding in polluted habitats expressed higher tolerance to ammonium both alone and in combination with nitrate and nitrite than two other reference populations exposed to lower nutrient concentrations in their environments. This result would suggest that populations breeding in habitats exposed to high levels of toxicant nitrogenous compounds may have evolved rapidly in response to environmental nitrification in a pronounced process of selection. This hypothetical rapid evolution, presumably caused by the intense farming activities developed in the polluted areas during the past three decades, is compatible with the idea that environmental stress, especially stress of contemporary anthropogenic origin, such as chemical pollution, is a strong force generating local adaptations and rapid evolution (Hoffmann and Hercus, 2000; Meyer and Di Giulio, 2003; Carroll et al., 2007). Previous studies revealed interpopulational variations in the tolerance to fertilizers of different amphibian species (Hecnar, 1995; Johansson et al., 2001; Hatch and Blaustein, 2003; Macías et al., 2007; Shinn et al., 2008), and local adaptation has also been suggested (e.g. Johansson et al., 2001, in Rana temporaria populations). In our case, the studied populations have been exposed to different nutrient concentration only during the last few decades (Vidal-Abarca et al., 2000; Ballester, 2003). Additionally, they belong to the same river basin and are located relatively close to each other, which may preclude strong demographic isolation between them. Although we have no information on population genetic structure, we could hint that the pattern of population divergence in P. perezi populations in nitrogenous compounds tolerance is concordant with an adaptive process involving natural selection. However, some caution is needed because the differences among populations do not appear consistent with regard to their origin, since the pattern observed for larval mortality does not ensue in the case of food consumption and final mass. Moreover, other factors may mask the divergent responses. For instance, egg masses were collected directly in the field, and, therefore, we can not discount the possibility that selective mortality and/or acclimatization process could be responsible for the responses observed (Freda and Dunson, 1984; Räsänen et al., 2003). Furthermore, no data exist on the heritable genetic mechanisms for nitrogenous compound tolerance and so, population divergence may be the response to other environmentally based sources such as maternal effects (Räsänen and Kruuk, 2007). All these considerations make it difficult to assess the interpretation of an adaptive response of populations to increased levels of eutrophication.

\section{Acknowledgements}

We thank Dr. María Luisa Suárez for her comments on eutrophication levels in the Segura River basin. We also thank Philip Thomas for the English translation. We are indebted to Dr. Anssi Laurila for his comments on the style and spelling of the English version of the manuscript. We acknowledge the Environmental Service of the Autonomous Government of Murcia, Spain, for providing the permits to collect the biological material used in this study. A. Egea-Serrano is supported by a Caja de Ahorros del Mediterráneo predoctoral fellowship.

\section{References}

Álvarez, D., Nicieza, G., 2002. Effects of temperature and food quality on anuran larval growth and metamorphosis. Funct. Ecol. 16, 640-648.

Baker, J., Waights, V., 1993. The effect of sodium nitrate on the growth and survival of toad tadpoles (Bufo bufo) in the laboratory. Herpetol. J. 3, 147-148.

Baker, J.M.R., Waights, V., 1994. The effects of nitrate on tadpoles of the treefrog (Litoria caerulea). Herpetol. J. 4, 106-108.

Ballester, R. (dir), 2003. Los humedales de la Región de Murcia: Humedales y ramblas de la Región de Murcia. Dirección General del Medio Natural, Consejería de Agricultura, Agua y Medio Ambiente, Región de Murcia.

Beebee, T.J.C., Griffiths, R.A., 2005. The amphibian decline crisis: a watershed for conservation biology? Biol. Conserv. 125, 271-285.

Berenbaum, M.C., 1989. What is synergy? Pharmacol. Rev. 41, 93-141.

Boone, M.D., Bridges-Britton, C.M., 2006. Examining multiple sublethal contaminants on the gray treefrog (Hyla versicolor): effects of an insecticide, herbicide and fertilizer. Environ. Toxicol.Chem. 25, 3261-3265.

Boone, M.D., Bridges, C.M., Fairchild, J.F., Little, E.E., 2005. Multiple sublethal chemicals negatively affect tadpoles of the green frog, Rana clamitans. Environ. Toxicol. Chem. 24, 1267-1272.

Burgett, A.A., Wright, C.D., Smith, G.R., Fortune, D.T., Johnson, S.L., 2007. Impact of ammonium nitrate on wood frog (Rana sylvatica) tadpoles: effects on survivorship and behavior. Herpetol. Conserv. Biol. 2, 29-34.

Camargo, J.A., Alonso, A., Salamanca, A., 2005. Nitrate toxicity to aquatic animals: a review with new data for freshwater invertebrates. Chemosphere 58, 12551267.

Carpenter, S., Caraco, N.F., Correll, D.L., Howarth, R.W., Sharpley, A.N., Smith, V.H., 1998. Nonpoint pollution of surface waters with phosphorous and nitrogen. Ecol. Appl. 8, 559-568.

Carroll, S.P., Hendry, A.P., Reznick, D.N., Fox, C.W., 2007. Evolution on ecological time-scales. Funct. Ecol. 21, 387-393.

De Wijer, P., Watt, P.J., Oldham, R.S., 2003. Amphibian decline and aquatic pollution: effects of nitrogenous fertiliser on survival and development of larvae of the frog Rana temporaria. Appl. Herpetol. 1, 3-12.

Díaz-Paniagua, C., 1990. Temporary ponds as breeding site of amphibians at a locality in Southwestern Spain. Herpetol. J. 1, 447-453.

Docampo, L., Vega, M.M., 1990. Contribución al estudio de la alimentación de Barbus bocagei (Steindachner, 1866), Phoxinus phoxinus (Linnaeus, 1758) y Rana perezi (Seoane, 1885) en ríos de Bizkaia. Sci. Ger. 16, 61-73.

Egea-Serrano, A., Oliva-Paterna, F.J., Torralva, M., 2005. Selección de habitat reproductor por Rana perezi Seoane, 1885 en el NO de la Región de Murcia (SE Península Ibérica). Rev. Esp. Herpetol. 19, 113-125.

Fenn, M.E., Baron, J.S., Allen, E.B., Rueth, H.M., Nydick, K.R., Geiser, L., Bowman, W.D., Sickman, J.O., Meixner, T., Johnson, D.W., Neitlich, P., 2003. Ecological effects of nitrogen deposition in the western United States. BioScience 53, 404-420.

Freda, J., Dunson, W.A., 1984. Sodium balance of amphibian larvae exposed to low environmental pH. Physiol. Zool. 57, 435-443.

Galloway, J.N., Aber, J.D., Erisman, J.W., Seitzinger, S.P., Howarth, R.W., Cowling, E.B., Cosby, B.J., 2003. The nitrogen cascade. Bioscience 53, 341-356.

Glos, J., Grafe, U., Rödel, M.O., Linsenmair, K.E., 2003. Geographic variation in pH tolerance of two populations of the European common frog, Rana temporaria. Copeia 2003, 650-656.

Gómez-Mestre, I., Tejedo, M., Ramayo, E., Estepa, J., 2004. Developmental alterations and osmoregulatory physiology of a larval anuran under osmotic stress. Physiol. Biochem. Zool. 77, 267-274.

Gosner, K.L., 1960. A simplified table for staging embryos and larvae with notes on identification. Herpetologica 16, 183-190.

Griffis-Kyle, K.L., 2005. Ontogenic delays in effects of nitrite exposure on tiger salamanders (Ambystoma tigrinum tigrinum) and wood frogs (Rana sylvatica). Environ. Toxicol. Chem. 24, 1523-1527.

Griffis-Kyle, K.L., 2007. Sublethal effects of nitrite on eastern tiger salamander (Ambystoma tigrinum tigrinum) and wood frog (Rana sylvatica) embryos and larvae: implications for field populations. Aquat. Toxicol.41, 119-127.

Hatch, A.C., Blaustein, A.R., 2000. Combined effects of UV-B, nitrate and low pH reduce the survival and activity level of larval Cascades frogs (Rana cascadae). Arch. Environ. Contam. Toxicol. 39, 494-499.

Hatch, A.C., Blaustein, A.R., 2003. Combined effects of UV-V radiation and nitrate fertilizer on larval amphibians. Ecol. Appl. 13, 1083-1093.

Hecnar, S.J., 1995. Acute and chronic toxicity of ammonium nitrate fertilizer to amphibians from Southern Ontario. Environ. Toxicol. Chem. 14, 2131-2137. 
Hoffmann, A.A., Hercus, M.J., 2000. Environmental stress as an evolutionary force. Bioscience 50, 217-226.

Holland, E.A., Braswell, B.H., Sulzman, J., Lamarque, J.F., 2005. Nitrogen deposition onto the United States and western Europe: synthesis of observations and models. Ecol. Appl. 15, 38-57.

Houlahan, J.E., Findlay, C.S., Schmidt, B.R., Meyer, A.H., Kuzmin, S.L., 2000. Quantitative evidence for global amphibian population declines. Nature 404, $752-755$.

Huey, D.W., Beitinger, T.L., 1980a. Hematological responses of larval Rana catesbeiana to sublethal nitrite exposures. Bull. Environ. Contam. Toxicol. 25, 574-577.

Huey, D.W., Beitinger, T.L., 1980b. Toxicity of nitrite to larvae of the salamander Ambystoma texanum. Bull. Environ. Contam. Toxicol. 25, 909-912.

Jofre, M.B., Karasov, W.H., 1999. Direct effect of ammonia on three species of North American anuran amphibians. Environ. Toxicol. Chem. 18, 1806-1812.

Johansson, M., Räsänen, R., Merilä, J., 2001. Comparison of nitrate tolerance between different populations of the common frog, Rana temporaria. Aquat. Toxicol. 54, $1-14$.

Llorente, G.A., Arano, B., 1997. Rana perezi. In: Pleguezuelos, J.M. (Ed.), Distribución y Biogeografía de los anfibios y reptiles en España y Portugal. Asociación Herpetológica Española-Universidad de Granada, Granada, pp. 164-166.

Llorente, G.A., Montori, A., Carretero, M.A., Santos, X., 2002. Rana perezi. In: Pleguezuelos, J.M., Márquez, R., Lizana, M. (Eds.), Atlas y Libro Rojo de los Anfibios y Reptiles de España. Dirección General de Conservación de la Naturaleza-Asociación Herpetológica Española, Madrid, pp. 126-128.

Macías, G., Marco, A., Blaustein, A.R., 2007. Combined exposure to ambient UVB radiation and nitrite negatively affects survival of amphibian early life stages. Sci. Total Environ. 385, 55-65.

Marco, A., Ortiz-Santaliestra, M.E., in press. Impact of reactive nitrogen on amphibians. In: H. Heatwole, (Ed.), Amphibian Biology, Conservation of Amphibians.

Marco, A., Quilchano, C., Blaustein, A.R., 1999. Sensitivity to nitrate and nitrite in pond-breeding amphibians from the Pacific Northwest USA. Environ. Toxicol. Chem. 18, 2836-2839.

Martín, J., Luque-Larena, J.J., López, P., 2006. Collective detection in escape responses of temporary groups of Iberian green frogs. Behav. Ecol. 17, 222-226.

Meyer, J.N., Di Giulio, R.T., 2003. Heritable adaptation and fitness costs in killifish (Fundulus heteroclitus) inhabiting a polluted estuary. Ecol. Appl. 13, 490-503.

Ortiz, M.E., Marco, A., Saiz, M., Lizana, M., 2004. Impact of ammonium nitrate on growth and survival of six European amphibians. Arch. Environ. Contam. Toxicol. 47, 234-239.

Ortiz-Santaliestra, M.E., 2008. Efectos de la contaminación por nitrógeno sobre la reproducción y el desarrollo de anfibios. PhD Thesis, University of Salamanca.

Orton, F., Carr, J.A., Handy, R.D., 2006. Effects of nitrate and atrazine on larval development and sexual differentiation in the Northern leopard frog Rana pipiens. Environ. Toxicol. Chem. 25, 65-71.

Pechmann, J.H.K., Scott, D.E., Semlitsch, R.D., Caldwell, J.P., Vitt, L.J., Gibbons, J.W., 1991. Declining amphibians populations: the problem of separating human impacts from natural fluctuations. Science 253, 892-895.

Pérez, M.T., Lemeunier, G., 2003. Los sistemas agrarios de la región murciana durante medio milenio (1500-2000). In: Esteve, M., Lloréns, M., Martínez, C. (Eds.), Los recursos naturales de la Región de Murcia. Un análisis interdisciplinar. Universidad de Murcia, Murcia, pp. 170-200.

Räsänen, K., Kruuk, L.E.B., 2007. Maternal effects and evolution at ecological timescales. Funct. Ecol. 21, 408-421.

Räsänen, K., Laurila, A., Merilä, J., 2003. Geographic variation in acid stress tolerance of the moor frog, Rana arvalis. I. Local adaptation. Evolution 57, 352-362.
Rist, L., Semlitsch, R.D., Hotz, H., Reyer, H.V., 1997. Feeding behavior, food consumption and growth efficiency of hemiclonal and parental tadpole of the Rana esculenta complex. Funct. Ecol. 11, 735-742.

Ritter, W.F., Bergstrom, L., 2001. Nitrogen and water quality. In: Ritter, W.F., Shirmohammadi, A. (Eds.), Agricultural Nonpoint Source Pollution: Watershed Management and Hydrology. Lewis Publishers, Boca Ratón, pp. 59-90.

Schuytema, G.S., Nebeker, A.V., 1999a. Comparative effects of ammonium and nitrate compounds on Pacific treefrog and African clawed frog embryos. Arch. Environ. Contam. Toxicol. 36, 200-206.

Schuytema, G.S., Nebeker, A.V., 1999b. Effects of ammonium nitrate, sodium nitrate, and urea on red legged frogs, Pacific treefrogs and African clawed frogs. Bull. Environ. Contam. Toxicol. 63, 357-364.

Shinn, C., Marco, A., Serrano, L., 2008. Inter- and intra-specific variation on sensitivity of larval amphibians to nitrite. Chemosphere 71, 507-514.

Smith, G.R., 2007. Lack of effect of nitrate, nitrite, and phosphate on wood frog (Rana sylvatica) tadpoles. Appl. Herpetol. 4, 287-291.

Smith, G.R., Vaala, D.A., Dingfelder, H.A., Temple, K.G., 2004. Effects of nitrite on bullfrog (Rana catesbeiana) tadpoles from central Ohio, USA. Bull. Environ. Contam. Toxicol. 72, 1012-1016.

Smith, G.R., Temple, K.G., Vaala, D.A., Dingfelder, H.A., 2005. Effects of nitrate on the tadpoles of two ranids (Rana catesbeiana and R. Clamitans). Arch. Environ. Contam. Toxicol. 49, 559-562.

Statsoft, 2001. STATISTICA (Data Analysis Software System) Versión 6. StatSoft, Tulsa.

Stuart, S.N., Chanson, J.S., Cox, N.A., Young, B.E., Rodríguez, A.S.L., Fischman, D.L., Waller, R.M., 2004. Status and trends of amphibians declines and extinctions worldwide. Science 306, 1783-1786.

Tejedo, M., 2003. El declive de los anfibios. La dificultad de separar las variaciones naturales del cambio global. In: X. Rubio. (Ed.), La conservación de los Anfibios en Europa. Munibe, vol. 16, (pp. 19-41).

Tilman, D., Fargione, J., Wolff, B., D́Antonio, C., Dobson, A., Howarth, R., Schindler, D., Schlesinger, W.H., Simberloff, D., Swackhamer, D., 2001. Forecasting agriculturally driven global environmental change. Science 29, 281-284.

Vaala, D.A., Smith, G.R., Temple, K.G., Dingfelder, H.A., 2004. No effect of nitrate on gray treefrog (Hyla versicolor) tadpoles. Appl. Herpetol. 1, 265-269.

Veeranagoudar, D.K., Shanbhag, B.A., Saidapur, S.K., 2004. Mechanism of food detection in the tadpoles of the bronze frog Rana temporalis. Acta Ethol. 7, 3741.

Vidal-Abarca, M.R., Montes, R., Ramírez-Díaz, L., Suárez, M.L., 1987. El clima de la cuenca del Río Segura (S.E. de España): factores que lo controlan. Anal. Biol. 12, $1-28$.

Vidal-Abarca, M.R., Suárez, M.L., Moreno, J.L., Gómez, R., Sánchez, I., 2000. Hidroquímica de un río de características semiáridas (Río Chícamo: Murcia). Análisis espacio-temporal. Limnética 18, 57-73.

Vitousek, P.M., Aber, J., Howarth, R.W., Likens, G.E., Matson, P.A., Schindlerm, D.W., Schlesinger, W.H., Tilman, G.D., 1997. Human alteration of the global nitrogen cycle: causes and consequences. Ecol. Appl. 7, 737-750.

Watt, P.J., Oldham, R.S., 1995. The effect of ammonium nitrate on the feeding and development of larvae of the smooth newt, Triturus vulgaris (L.), and on the behaviour of its food source, Daphnia. Freshwater. Biol. 33, 319-324.

Wright, P.M., Wright, P.A., 1996. Nitrogen metabolism and excretion in bullfrog (Rana catesbeiana) tadpoles and adults exposed to elevated environmental ammonia levels. Physiol. Zool. 69, 1057-1078.

Xu, Q., Oldham, R.S., 1997. Lethal and sublethal effects of nitrogen fertilizer ammonium nitrate on common toad (Bufo bufo) tadpoles. Arch. Environ. Contam. Toxicol. 32, 298-303. 